\title{
A scoping review of the incentives for a prolonged work life after pensionable age and the importance of "bridge employment"
}

\author{
Anita Björklund Carlstedt ${ }^{\mathrm{a}, \mathrm{b}, *}$, Gunilla Brushammar ${ }^{\mathrm{c}}$, Cecilia Bjursell ${ }^{\mathrm{d}}$, Paul Nystedt $\mathrm{C}^{\mathrm{e}, \mathrm{f}}$ \\ and Gunilla Nilsson ${ }^{\text {b,g }}$ \\ ${ }^{a}$ Department of Rehabilitation, School of Health and Welfare, Jönköping University, Jönköping, Sweden \\ ${ }^{\mathrm{b}}$ Ageing Research Network - Jönköping (ARN-J), Jönköping University, Jönköping, Sweden \\ ${ }^{\mathrm{c}}$ University Library, Jönköping University, Jönköping, Sweden \\ ${ }^{\mathrm{d}}$ National Centre for Lifelong Learning, School of Education and Communication, Jönköping University, \\ Jönköping, Sweden \\ e Jönköping International Business School, Jönköping University, Jönköping, Sweden \\ ${ }^{\mathrm{f}}$ Jönköping Academy for Improvement of Health and Welfare, Jönköping University, Jönköping, Sweden \\ ${ }^{\mathrm{g}}$ Department of Behavioural Science and Social Work, School of Health and Welfare, Jönköping University, \\ Jönköping, Sweden
}

Received 25 November 2016

Accepted 28 November 2017

\begin{abstract}
.
BACKGROUND: With a growing share of older people in almost every population, discussions are being held worldwide about how to guarantee welfare in the immediate future. Different solutions are suggested, but in this article the focus is on the need to keep older employees active in the labor market for a prolonged time.

OBJECTIVE: The aim was to find out and describe the incentives at three system levels for older people 1) wanting, 2) being able, and 3) being allowed to work.

MATERIAL: The literature search embraced articles from the databases Scopus, PsycInfo, Cinahl, AgeLine and Business Source Premier, from May 2004 until May 2016. After the removal of 506 duplicates, the selection and analysis started with the 1331 articles that met the search criteria. Of these, 58 articles corresponded with the research questions.

METHOD: The design was a 'scoping review' of the research area bridge employment and prolonged work life.

RESULTS: The results show that most investigations are conducted on individual-level predictors, research on organizationallevel predictors is more scattered, and societal-level predictor information is scarce.

CONCLUSIONS: Attitudes and behavior according to a prolonged work life could be summarized as dependent on good health, a financial gain in combination with flexible alternative working conditions.
\end{abstract}

Keywords: Career jobs, organizational levels, old workforce, older employees, self-employed

\footnotetext{
*Address for correspondence: Anita Björklund Carlstedt, Jönköping University, School of Health and Welfare, Department of Rehabilitation, Box 1026, 55111 Jönköping, Sweden. Tel.: +46 33 101266/46 708 261250; E-mail: Anita.Bjorklund@ju.se.
}

\section{Introduction}

A growing share of older people in almost every population is a global and well-known phenomenon, and discussions are being held worldwide about how to guarantee the welfare of old people in the 
immediate future. A lack of financial resources (to pay for welfare) and a forthcoming shortage of staff are constantly on the agenda [1,2]. Different solutions are suggested, like engaging a larger part of the younger generation [1], but in this article the focus is on the need to keep older employees active in the labor market for a prolonged time. Additionally, there is a growing group of older employees who want to stay active and prolong their time in the labor market. This group is currently already active in different parts of the labor market in so-called "bridge employment", as well as in the informal caring sector [3]. The human capital factors such as formal education, work experience, and health have had a significant impact on the likelihood of individuals working late in life [4]. However, there are also employees who cannot or will not prolong work life due to different obstacles.

Several studies put forward the influence of motivational changes later in life [5-9]. "Prime movers" to stay in work life may co-exist with driving forces to retire [10]. Both internal (meaning of work) and external (performance) motivational factors can explain a prolongation of work life [8] and there are studies stressing a transition from external to internal driving forces with increasing age [11]. In contrast to earlier studies regarding solely motivational factors associated with the person, this study applies an integrated frame of reference with three system levels, in line with Shultz [12], to enhance the understanding of willingness to stay in work [7]. This knowledge is important when it comes to developing new methods and strategies for example supporting systems, work environment strategies, and competence developing strategies to encourage older people to be willing, able and allowed to work longer.

Shultz's [12] model of prolonged work life after reaching pensionable age comprises three interactive components belonging to different system levels, see Fig. 1.

The components are: personal attributes, i.e. the individual's ability and volition to work longer (micro level); work opportunities, i.e. organizational prerequisites within companies and employers (meso level); and the socio-cultural context in society and in the country in question (macro level). In our study the model served to structure information and to understand the different aspects making a prolonged work life possible. Additionally, we adopted and interpreted Beehr and Bennett's [13, p. 122] definition of 'bridge employment' as "working for pay after retirement" in three different ways: 1) continued salaried work, full or part time, for the

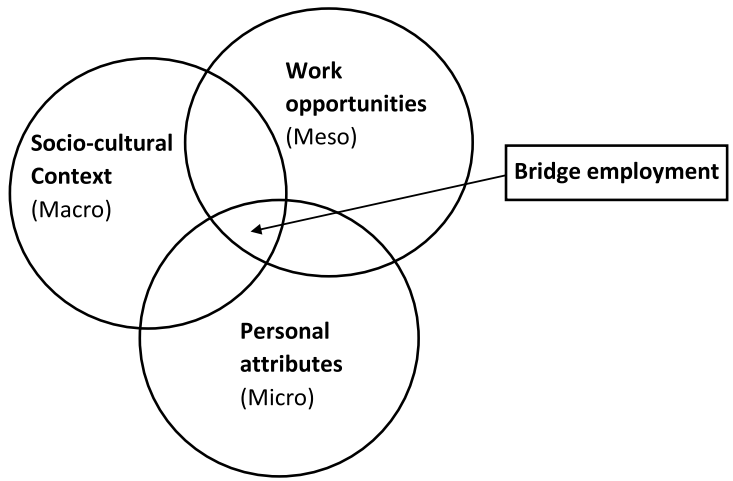

Fig. 1. Bridge employment seen from three system levels (Freely from Shultz, 2003).

same employer as before (career jobs); 2) working permanently or temporarily for a new employer, or 3 ) as self-employed [14].

However, what is regarded as "pensionable age" differs in time between individuals and different countries in Europe. In Sweden, there is no official pensionable age, but 65 is the age when the guarantee pension is available [15]. Accrued pension can be received from the age of 61 . Most people seem to view 65 as the normal retirement age even if the way they think about and understand retirement differs according to whether there are a few years remaining before making a decision, if it is time to make a decision, or a few years has passed since retirement. Consequently, their view of keeping on working after pensionable age could also differ according to the time perspective in question. At the age of 67 the rules of priority in employment and the law of employment security expire [15]. At this age one can be forced to leave employment, but there is nothing per se to say that the older employee is not able to continue to work.

There are several reasons for a continued work life at a micro level: achieving new skills, new learning, a new career, a better pension, and being part of an active lifestyle with stimulating relationships with colleagues $[16,17]$. But if a continued work life should be possible for the individual we need to incorporate also the meso and macro levels in a framework where research, policy and operations are integrated and linked together [18].

\section{Aim}

The aim of our study was to find out and describe the incentives at three system levels for older people 1) wanting, 2) being able, and 3) being allowed to work. 
Table 1

Search matrix

\begin{tabular}{|c|c|c|c|c|}
\hline $\begin{array}{l}2014-05-23 \\
\text { Scopus }\end{array}$ & Number of hits & $\begin{array}{l}\text { Hits minus } \\
\text { (duplicates) }\end{array}$ & $\begin{array}{l}\text { Chosen abstracts } \\
\text { Bold }\end{array}$ & $\begin{array}{l}\text { Chosen articles } \\
\text { Green }\end{array}$ \\
\hline $\begin{array}{l}\text { "Bridge employment" OR KEY ("older workers" } \\
\text { OR "Employment of older workers") OR "aging } \\
\text { workforce" OR "aging employees" }\end{array}$ & 607 & $607(0)$ & Color 195 & 33 \\
\hline $\begin{array}{l}\text { Year: 2004-, English Document type: Article, } \\
\text { Review, In press Source type: Journal }\end{array}$ & & & & \\
\hline $2015-05-28$ & 122 & $122(0)$ & 16 & 1 \\
\hline $2016-05-28$ & 113 & $89(24)$ & 24 & 5 \\
\hline \multicolumn{5}{|l|}{ PsycInfo } \\
\hline $\begin{array}{l}\text { "bridge employment" OR SU ("older workers") OR } \\
\text { "aging workforce" OR "aging employees" }\end{array}$ & 273 & $129(144)$ & 20 & 6 \\
\hline \multicolumn{5}{|l|}{ Peer reviewed, Date: After 2004, Language: English } \\
\hline $2015-05-28$ & 35 & $7(28)$ & 1 & 0 \\
\hline $2016-05-28$ & 28 & $6(22)$ & 0 & 0 \\
\hline \multicolumn{5}{|l|}{ Cinahl } \\
\hline $\begin{array}{l}\text { "Bridge employment" OR MH (Employment of } \\
\text { Older Workers OR Employment In Old Age OR } \\
\text { Workforce In Old Age) OR "aging workforce" } \\
\text { OR “aging employees" }\end{array}$ & 113 & $55(58)$ & 5 & 1 \\
\hline Peer review, Research article, English, 2004- & & & & \\
\hline $2015-05-28$ & 8 & $7(1)$ & 0 & 0 \\
\hline $2016-05-28$ & 10 & $2(8)$ & 2 & 0 \\
\hline \multicolumn{5}{|l|}{ AgeLine } \\
\hline $\begin{array}{l}\text { "Bridge employment" OR DE "Older Workers" OR } \\
\text { "aging workforce" OR “aging employees" }\end{array}$ & 230 & $159(71)$ & 35 & 6 \\
\hline \multicolumn{5}{|l|}{$\begin{array}{l}\text { Publication Year: 2004-Publication Type: Journal } \\
\text { Article }\end{array}$} \\
\hline $2015-05-28$ & 7 & $6(1)$ & 5 & 2 \\
\hline $2016-05-28$ & 18 & $12(6)$ & 3 & 0 \\
\hline \multicolumn{5}{|l|}{ Business Source Premier } \\
\hline $\begin{array}{l}\text { "Bridge employment" OR (DE "OLDER people - } \\
\text { Employment" AND aging) OR "aging workforce" } \\
\text { OR "aging employees" }\end{array}$ & 218 & $109(109)$ & 30 & 4 \\
\hline $\begin{array}{l}\text { LA English, 2004-, Document type Article } \\
\text { Scholarly, Number of pages: }>2\end{array}$ & & & & \\
\hline $2015-05-28$ & 29 & $12(17)$ & 0 & 0 \\
\hline $2016-05-28$ & 27 & $10(17)$ & 4 & 0 \\
\hline Total number: & 1838 & $1332(506)$ & 340 & 58 \\
\hline
\end{tabular}

\section{Material and method}

The design of this study is a 'scoping review' with the objective being to map the extent, range and nature of the research $[19,20]$ within the area of bridge employment and prolonged work life after pensionable age.

\subsection{Research questions}

- What characterizes older persons working after retirement? (Micro level)
- What characterizes the work life conditions for older persons? (Meso level)

- What characterizes the socio-cultural contexts for older persons' work life? (Macro level)

\subsection{Literature search and selection of articles}

A literature search was made by one of the authors (a university librarian) in the databases Scopus, PsycInfo, Cinahl, AgeLine and Business Source Premier, in May 2014 and ten years back (2004-2014). Two additional searches were then conducted in May 2015 and May 2016, for articles from the 


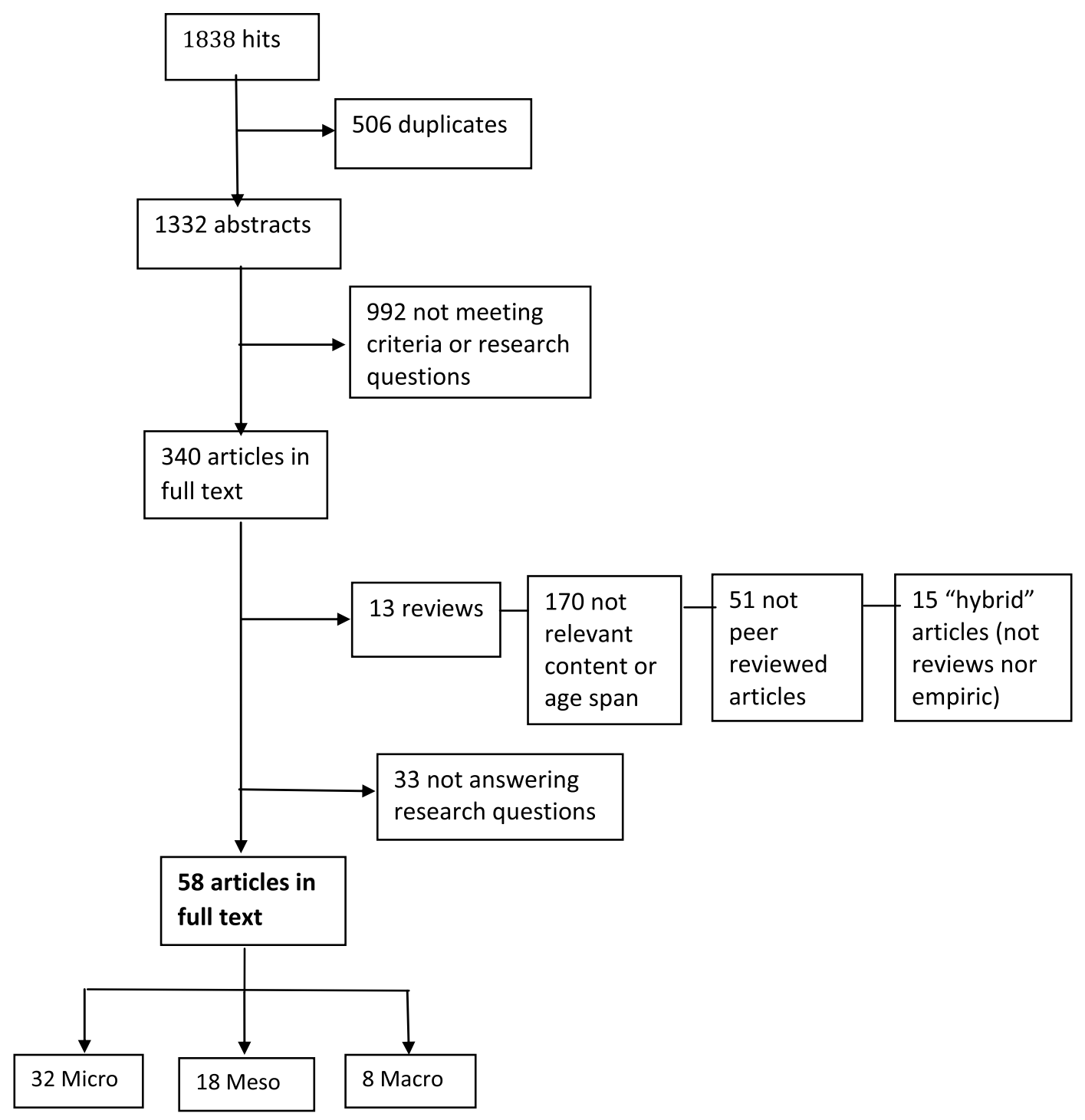

Fig. 2. Flowchart of the selection and reading of articles.

last two years. The search terms were thesauriterms specific for each database, supplemented with "bridge employment", "aging workforce" and "aging employees" as free text in all databases. Choice limiters were: peer reviewed or scholarly (where possible), English language and in some cases article length of 3 pages or more. The limit in pages was used to help find refereed articles, as the limiter "peer review" only can restrict to peer reviewed journals (not articles). For an exact search protocol, search combinations, hits and selection of articles, please see the matrix in Table 1.

After the removal of 506 duplicates, the selection and analysis of articles started with the 1332 arti- cles that corresponded to our search criteria, from May 2004 until May 2016 - see Fig. 2. For the selection process the librarian had created an Excel file comprising the 1332 articles, showing: ID no, author, year, title, journal, database, space for comments and abstract.

To ensure a solid interrater reliability of $70 \%$ in the commonly selected abstracts, the first and last author read the abstracts individually, in a parallel and stepwise fashion, until this was accomplished (when 280 abstracts were read) - see Table 2 for this stepwise process.

As shown above, the percentage of individually read and commonly selected abstracts in column two 
Table 2

The reading process for ensuring reliability of selection

\begin{tabular}{lcc}
\hline Abstract no & $\begin{array}{c}\text { Commonly selected } \\
\text { abstracts (\%) }\end{array}$ & $\begin{array}{c}\text { Abstracts selected } \\
\text { after discussion (\%) }\end{array}$ \\
\hline $1-80$ & 49 & 59 \\
$81-120$ & 65 & 73 \\
$121-160$ & 65 & 50 \\
$161-200$ & 58 & 38 \\
$201-240$ & $\mathbf{8 2}$ & 24 \\
$241-280$ & $\mathbf{7 5}$ & 28 \\
\hline
\end{tabular}

grew. The third column shows selected abstracts after further discussion where the authors became more selective concerning which articles to keep.

The remaining 1052 (of the 1332) articles were divided equally between the two authors, database to database. Abstracts that seemed to match our selection criteria and research questions were marked with bold text in the Excel file. This resulted in 340 abstracts, including those chosen from the first 280 read abstracts, and selected for further reading of the whole article. In parallel with the reading of the 340 articles, they were marked with a color:

- Blue - review articles (not to be included in our review) (13)

- Yellow - irrelevant content (170)

- Red - not a scientific, peer reviewed article in English (51)

- Grey-hybrid (not empirical but theoretical, case studies or discussion papers (15)

- Green - selected for further reading according to research questions (91)

The repeated reading of the 91 articles (green) resulted in the exclusion of 33 additional articles that did not respond to the research questions. The remaining 58 articles were then sorted in relation to the three system levels of bridge employment. For an overview of this procedure, see the flow chart in Fig. 2.

\subsection{Data matrix}

A matrix of the selected 58 articles was developed to collate, summarize and report the results according to the research questions. The matrix contained the following items:

- Number $1-58$

- Database and no. (from Excel file)

- Reference/Country

- Micro/Meso/Macro level of the study

- Aim

- Material/Method

- Results/Conclusions
The whole data matrix is available from the corresponding author, but for an example please see Table 3.

\section{Results}

The results are presented in two ways in line with Arksey and O'Malley [19]. First, attention is given to the numerical analysis of the extent, nature and distribution of the studies in the review. Second, the literature is organized thematically according the three research questions and system levels in line with Shulz [12].

Fifty-eight articles responded to our research questions: thirty-two on micro level (personal attributes), eighteen on meso level (organizational prerequisites) and eight on macro level (socio-cultural context). The distribution of articles according to publication year during the twelve-year search period (2004-16) is presented in Table 4.

There are two clusters of years where most of the articles were published, 2008-09 with thirteen articles and 2011-13 with twenty-five articles. Twenty-three countries are represented in the fifty-eight selected articles, see Table 5. The most commonly occurring country is the USA in 22 of the 58 , followed in descending order by the Netherlands in 11 , Canada in 6, the United Kingdom in 6, Australia in 5, Sweden in 5, and the rest of countries in 1-4. Thirty-nine of the studies were conducted as survey studies with questionnaires to large populations, fourteen with qualitative methodologies and five with combined methodologies.

\subsection{Older persons working after retirement}

Decisions made by the generation born in the late forties and fifties, often called the "baby boomers", on whether to leave the labor market permanently or to turn to bridge employment, are discussed in several articles, presenting data from empirical studies. The studies are built on questionnaires and/or interviews with elderly persons who are in the process of making these decisions, or who have already done so. The following studies from different countries all over the world highlight three characteristics on the individual level for working longer: a good health, monetary gain and having a better education.

An American study of changes in retirement plans by early baby boomers shows that permanent exits from the labor force continue to be the excep- 


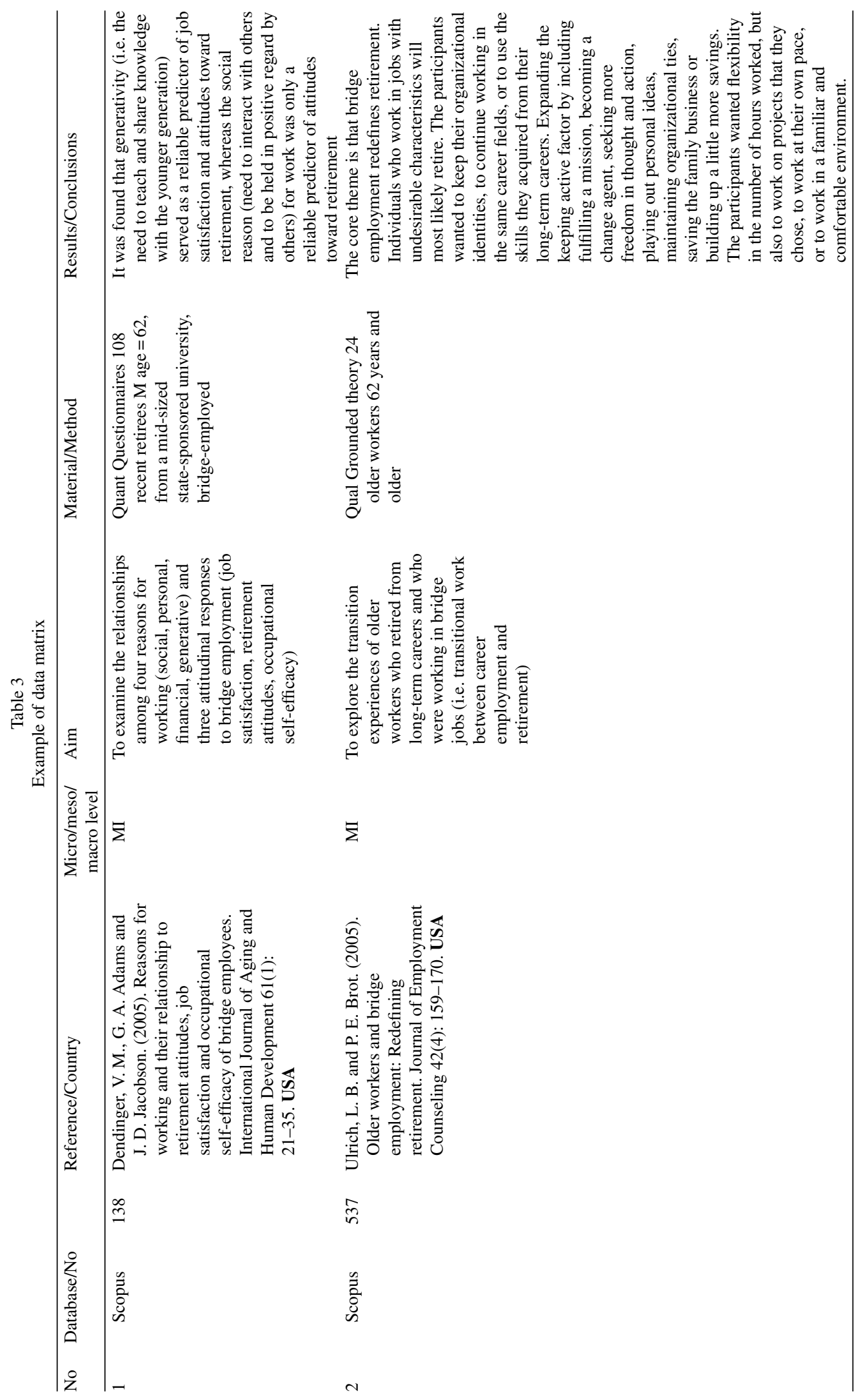


Table 4

Selected articles and distribution according to publication year

\begin{tabular}{rrlll}
\hline Year & F & Micro & Meso & Macro \\
\hline 2004 & 2 & & & 72,75 \\
2005 & 5 & $24,30,37,40$ & 62 & \\
2006 & 0 & & & 73 \\
2007 & 3 & 38 & 65 & \\
2008 & 6 & $23,28,42,45,50$ & 66 & 70,74 \\
2009 & 7 & 46,47 & $57,58,59$ & \\
2010 & 4 & $11,22,39$ & 64 & 77 \\
2011 & 7 & $26,27,31$ & $53,56,60,69$ & \\
2012 & 10 & $32,35,41,43,44$ & $55,63,67,68$ & 77 \\
2013 & 8 & $21,33,36,48$ & 52,61 & 71,76 \\
2014 & 2 & 34,51 & & \\
2015 & 2 & 29,49 & 54 & \\
2016 & 2 & 25 & 18 & \\
Total & 58 & 32 & &
\end{tabular}

Table 5

Represented countries in articles

\begin{tabular}{llc}
\hline Country no & Country & Number of articles \\
\hline 1 & Australia & 5 \\
2 & Belgium & 1 \\
3 & Canada & 6 \\
4 & China & 1 \\
5 & Denmark & 2 \\
6 & France & 3 \\
7 & Germany & 4 \\
8 & Greece & 1 \\
9 & Iran & 1 \\
10 & Israel & 1 \\
11 & Italy & 3 \\
12 & Japan & 1 \\
13 & Netherlands & 11 \\
14 & New Zeeland & 1 \\
15 & Philippines & 1 \\
16 & Poland & 1 \\
17 & Spain & 1 \\
18 & Sweden & 5 \\
19 & Switzerland & 1 \\
20 & Thailand & 1 \\
21 & Taiwan & 2 \\
22 & United Kingdom & 6 \\
23 & USA & 22 \\
\hline
\end{tabular}

tion, rather than the rule [21]. To former traditional retirement income, the authors added social security, private pensions and savings as benefits from continued work. On an individual level, several conditions have shown to be of importance for this choice [22]. The results from a study in Japan revealed that the probability of working past age 65 increased with higher education and good health [23]. Additionally, a longitudinal study of 231 participants in Israel [24] showed that for the 135 participants who were working at age 70 , work correlated positively with health, self-sufficiency and longevity, independent of baseline status. Similar results came from a study of employability after 75 in Australia [25] where good health was highlighted. The importance of health was also stressed in a Canadian study to be the only shared factor positively influencing both work commitment and the intention to work [26]. Additionally, good health status, often in combination with more years of education, was associated with a stronger intention to remain in bridge employment in studies from both the Netherlands and the United Kingdom, and the USA [27, 28]. The importance of good health was also raised in a small study of retired Iranian male and female nurses [29]. As the retirement age is lower in Iran (60 years for males and 55 for females), the motivational factors for reentering the labor force were first of all "serving society", followed by maintaining and promoting their own health, and maintaining their role and activity.

The decision to work in advanced old age is a matter of choice that healthy, American men can make, and was strongly related to their spouses' concurrent work [30]. This choice was also stressed in a large prospective study in Sweden [31] where 1792 respondents, mostly female aged 55-64 and working in the health sector, were asked if they believe they can and wanted to work until the age of 65 or beyond. Fifty-four percent answered they can work, and 38\% said they wanted to work until 65 and beyond. The "can work" statements were strongly associated with health and economic incentives, while the "want to" work statements were strongly associated with management attitudes, physical work environment, working pace and working time. However, economics and retirement decisions made by life partners played the most important role. Employees in the USA who are eligible to retire might also feel encouraged to stay longer than they had planned if benefits like health care were provided by the employer [32]. Consequently, being active in the labor market is, as emphasized above, a question of having good health.

More people with poor health leave the labor market early, or change jobs, with reference to a study from the United Kingdom [33]. If, on a more psychological level, the experience of aging is seen as a period of physical loss, a force for post-retirement employment might be seen as an additional burden to health conditions and thus be rejected, according to a study from Germany and the USA [34]. This is confirmed by a study from Taiwan [35] showing that those with better self-images or more positive outlooks towards aging are more inclined to continue working in older age. The negative impact of poor health on the intention to remain in the labor market 
can, however, be affected if individuals are allowed to make some important choices concerning selection, optimization and compensation when accepting offered jobs [36] as in a study from Germany and the Netherlands. Even if different aspects of health were emphasized as an important incentive for older employees remaining longer in the workforce in several articles [24, 26-28, 30-34, 36, 37], we found no articles in our sample supporting evidence for the question of whether, and if so how, a prolonged time in the labor market would affect health negatively.

A second aspect of the interest in or willingness to work beyond the age of 65 is the question of monetary gain. It is important for employers to understand "how to become more successful at targeting older workers in recruitment" [38], and this is emphasized in a study from Southern California, USA. The financial motives for staying longer in the labor market are numerous and complex. The need for money was a major motivating factor for Canadian females seeking a bridge employment job [39]. The same results were shown in a study of retirees aged 62-69 who received social security benefits [38]. Respondents in this group were interested in part-time work and flexible working hours. Another incentive, more freedom in "thought and action", is also put forward in a qualitative study from the USA [40] as being important for continuing to work. Adding to these benefits, Medicare was also seen as an interesting incentive [38].

Economic incentives for working longer were also part of the answers in a Swedish study [31], and were also supported by answers in a small study from the USA [32]. Even if non-monetary gains and intrinsic values, like the need for generativity, socialization, and continuity, are valued as therapeutic in some jobs, the monetary gain and financial considerations were major reasons for a group of university teachers in the Philippines working past retirement in bridge employment [41]. Additionally, the results from a large study from urban China [42] illustrate that those with higher incomes were less likely to retire and more likely to work - contrary to findings in OECD countries. Another finding in this study was that those who were still active in the labor market were less likely than retirees to have pension support and health insurance coverage.

As shown above, there are multiple reasons for staying active and starting an encore career, and, to put it rather instrumentally, paid work is a path to material resources for both the individual and society. However, a study from New Zeeland also shows that older people see this as a way to achieve self-actualization [43], and if suspiciously taken, as seductive paths for older people to take individual responsibility and absolve society of responsibility for their well-being.

A third factor of importance for older employees' decisions to add more years in the labor market is having better education and attractive skills, which are important for both the employer's interest in offering possibilities to prolong work life and the employee's own interest in doing so. Education in itself makes a major difference, as highly educated men - and also women - tend to work longer according to studies from several countries [23, 25, 28, 30, 44, 45]. Men from the USA with a better education also perceived the labor market to be good and joined bridge employment as they wanted to make better use of their skills, and were also willing to move into a different field [46]. They also enjoyed a workplace where their skills were appreciated [47], or could be developed [32], as in self-employment, like in studies from the Philippines [41] and the Netherlands [48].

How the labor market is viewed, and how one's own employability is perceived, differs between generations and suggests that "older workers" is not a homogeneous group. In interviews with older workers from the Netherlands the results showed that the veteran generation differed from the baby boomers in how they perceived their employability as being connected to their skills, while the baby boomers stressed external factors like negative stereotypes and being viewed as far too expensive to employ [49].

Older persons who contribute to the labor market in the USA highlight the question of generativity, job satisfaction and their own or others' attitudes towards retirement. The older persons also stated that having the possibility to share knowledge with the younger generations served as a reliable predictor of job satisfaction and positive attitudes to later retirement. However, a proportionally higher number of older workers in the Netherlands avoided dominant mastery, thus focusing on being less competitive [11].

Additionally, social needs are known as an incentive for older persons to return to work. The loss of social interaction, or the need for mental stimulation, as shown in studies from Sweden [50] and the Philippines [41], are strong. Finding a bridge job increases life satisfaction for those willing and able to work, while not finding a desired job decreases life satisfaction, as shown by a study from the Netherlands [51]. Further, the social aspect might be seen 
as less important even if it is often mentioned, as few respondents count this as a reason for prolonging their working years. Nevertheless, among those who do work longer, the social part of their work life is highly valued. This means that individuals with self-assessed ill health tend to leave work life earlier, and the possibilities for social contact do not change this.

In summary: Those who stay beyond pensionable age in the labor market have some characteristics in common: they are in good health, they are interested in monetary gain, and they have good education and skills suitable for the labor market. However, there are also other incentives for prolonging work life, such as social needs, maintaining organizational identity, roles and activity, and spouses' work status.

\subsection{Work life conditions for older persons}

Turning to the meso- or organizational level, the analyzed research articles are commonly structured along lines of "facilitators" and "barriers" for a prolonged working life. There is need for a cultural change to prevent early work exit, which is a widelyaccepted practice, [52], since the many workers who leave during economic downturns might be hard to reengage later, and losing older workers entails a drain of knowledge and expertise. Being aware of these conditions, some employers are looking for new ways to retain older workers and at the same time encourage employees to reevaluate the traditional approach to retirement $[52,53]$.

Facilitators - things like training, lifelong learning, flexible workhours, health protection and job design - are all representatives of good pathways of practice. However, as the authors stress, these good examples are rarely highlighted in the debate. Education is also closely related to lifelong learning as a key element of the inclusion of older workers [54]. Additionally, there are actually good results when it comes to innovative solutions to meet the challenge of an aging workforce [55]; Designing jobs to meet the general need for older workers is one important innovation. A small-scale study [56] reveals some of the facilitating characteristics: opportunities for decision-making, skill variety, coworkers' support, and supervisors' support.

Employers who can offer rearrangement of work, and provide financial rewards and appreciation, are more likely to encourage their employees not to retire early [57]. Other ways for employers to keep their staff include offering organizational support and career satisfaction, as well as supporting older staff. These findings show the need for employers to support older workers to upgrade skills as well as acquiring new skills [58]. While some studies have stressed the benefits of financial rewards, other studies stress the absence of competing interests, maintaining a healthy lifestyle, and education as facilitators for a prolonged work life [59]. Having a stimulating job was among the most important reasons for not taking full retirement [57].

Added to these facilitators for staying longer at work was the possibility to make decisions, to use a variety of skills and to experience good co-worker support. All this contributed to a healthy aging outcome [56].

Barriers for older workers to delay their retirement can sometimes be created by the workplace itself. Job demands like stress, lack of support, physical demands and an overemphasis on qualifications act as barriers to workers' ability to delay retirement [59]. The share of the workforce in the USA in physically demanding jobs has been falling during the last 40-50 years, while the share of cognitively demanding work has increased [60]. This may limit options for some older workers with less education, if support is not offered.

Older workers must deal with stereotypes, both negative and positive, directed at them from younger workers. Age stereotypes are reported in different studies of age discrimination in the labor market. A cross-national study from 2013 [61] confirms that younger workers in the USA and Thailand generally viewed older workers as being more uncomfortable with new technology, less flexible, and more cautious at work. However, the older workers were also seen as being more loyal and having less absence.

Systematic negative stereotyping might lead employers to be less interested in hiring older workers [62], even if the need to maintain older workers is growing. This could mean that older workers who are looking for a new employment will have difficulties finding one. They will often be forced into the "Lopaq" sector, known for low payment, often involving part-time work with low demands in terms of qualifications [63]. In Britain, more than half of those employed in their $60 \mathrm{~s}$ had a job in the Lopaq sector. Barriers of discrimination could also arise from the new UK government's "business case" approach where the decision on whether a person is welcome to work beyond the age of 65 rests with the line manager rather than the senior manager or human resources specialist [64]. Further, this prac- 
tice conflicts with the national discussion on whether or not to increase the state pension age in the United Kingdom [65, 66].

Retirement of the baby boom generation, approximately 78 million people in the United States, will lead to a massive increase in retirees, which will impact on organizations in many ways [67]. However, only $21 \%$ of organizations around the world stated that they had strategies in place to retain older workers [67]. Industry knowledge and expertise often leaves with them, unless businesses construct a mentoring or retiree engagement program to transfer knowledge to younger generations. There is a lack of organizational energy on the part of employers to keep their staff, even if they are worried about a larger gap between labor costs and productivity [68]. Only a minority of employers has applied to recruit or retain older workers, preferring to retain rather than hire older workers. However, the study also reveals restricted knowledge about employers' attitudes and actions towards an extension of their employees' years in the labor market.

As presented above, employees' interest in prolonging their years in the labor market is a complicated question, and even though support from the organization is often asked for, it is not always enough to persuade employees to stay. This is illustrated in a small study of 123 teachers showing that organizational support and a change in their work role was only positively related to motivation to continue working for those who wanted to continue with the same kind of work after retirement [69].

In summary: Workplaces that manage to encourage their staff to work past the age of 65 have several characteristics in common. Facilitators are offering financial gains, meeting individuals' desire to contribute, flexible working hours, and the possibility to upgrade exiting skills and acquire new skills. Other factors include health protection and promotion. Barriers include stress, a lack of support, negative attitudes, physical and cognitive demands, and an overemphasis on lack of qualifications.

\subsection{Socio cultural contexts for older persons' work life}

Turning to the macro level (sociocultural context), and the need to increase the proportion of older workers in the labor market due to future costs for pensions and health care, in combination with a future labor shortage, our material shows one main way to achieve this:
Raising the financial benefits for those who continue working beyond pensionable age, as either a raised wage [70] or a differentiated tax [71]. The reasons that large groups leave the labor market are the different ways to use the mandatory pensionable year as a push factor [72]. In a Canadian study, where the authors elaborated on the idea of making mandatory retirement illegal, this was shown to have little effect on the size of the workforce. One plausible explanation for this result was that trends towards early retirement, and the factors that had driven these trends, have reduced the demand for delayed retirement. This implies that fewer people were effectively constrained by mandatory retirement practices.

Conversely, the findings from a study in the USA and Canada [73] showed that over the last ten years the early baby boomers have tended to increase their working years. Lower rates of retiree health insurance offered by employers, higher levels of educational attainment, and lower rates of defined benefit pension coverage accounted for most of the growth, according to the study. Further, the authors stressed that given the continued erosion of employer-sponsored retiree health benefits and defined benefit pension plans, baby boomers will likely remain at work longer than members of the previous generations. Additionally, changes to social security benefits, like those implemented in the USA, have affected the recent retirement trends with men aged 65-67 being more likely to work full-time in 2004 than in 1998 [74].

Improved health due to less demanding physical jobs and better education is another explanation for a prolonged work life. However, this is not true for all groups on the labor market. Depending on race and gender, education might be lower and income weaker in older age [75]. Many Americans who may retire earlier from their full-time job make the transition to bridge employment with the addition of volunteering jobs or caring for relatives. However, as seen above, personal living conditions also affect public engagement. Caring duties reduce the odds of doing paid work but not volunteering. But again, health and education play a role, and individuals with poor health, less education and low income are less likely to do volunteering jobs [76]. A question that is less visible in our material is the gender dimension. Not only do women in several countries contribute more to the increased employment rate, they also take a greater responsibility for assisting dependent relatives [77]. 
In summary: There is a growing trend among the early baby boomers to increase their working years. Economic, social and demographic trends, as well as changing social security rules, may affect the future growth of encore working. Due to strengthened national finances and improved public health, some countries are now using economic incentives to encourage an interest in bridge employment. Still, with a growing need for staff in the labor market, a lack of education or not having the right skills are important factors that might result in unemployment or temporary low-paid jobs.

\section{Discussion}

Several international reviews of a prolonged work life have been conducted during the last ten-year period, with Beehr and Bennett's [13] being one of the most recent. In line with the results of our review, they found that most investigations are conducted on individual-level predictors, research on organizational-level predictors is more scattered, and societal-level predictor information is scarce. An earlier review by Quine and Carter [78], who found that many of the reviewed articles are opinion articles and not grounded on empirical studies, is also in line with our results.

The most evident knowledge gap was consequently identified at the macro level, where few studies matched our research question. Even though Sweden faces challenges when it comes to keeping older people in the workforce in order to limit the dependency ratio and secure labor supply, it should be stressed that labor force participation, especially by females, average retirement age and total length of work life are already relatively high in Sweden. The mean length of work life in Sweden has been estimated at 40 years in 2011, placing Sweden third among the European countries [15] (based on Eurostat figures). Furthermore, the average effective retirement age has increased by almost three years between the mid-1990s and 2012 [79]. Still, there is a huge agerelated drain from the labor force, and participation decreases from almost $90 \%$ in the 55-59 age group to $20 \%$ in the 65-69 age group, with less than $10 \%$ of people aged 70-74 working [15]. This knowledge is essential for policy making directed towards bridge employment for older adults' prolonged work life. Hence, it is important to remember that older people are not a homogeneous group and that individual traits exist in all ages [80]. Questions of personal attitudes and behavior according to retirement are also dependent to a high degree on contexts in time and place.

Many people may perceive work to be a highly meaningful activity in old age, finding pleasure in it and therefore being motivated - if their health is at least fairly good - to continue to work, and to learn new things. Research on the health aspect of working beyond pensionable age show that people with good health are active in bridge employment, while people with poor health have left work life at, or before, pensionable age. That, however, does not answer the question of whether or not a prolonged work life supports good health. A correlation has been shown [24] between prolonged working until 70 years of age and better health at 77 compared to non-workers.

In research findings on education later in life, there is a distinction between education in a workplace context and education later in life in general. One reason for this could be that research reflects the current state of age division, and that due to the retirement age, individuals are not considered part of the potential workforce after retirement and thus do not participate in work-related training and/or education. There seems to be an invisible line between education before and after retirement. Research on workplace education defines older as 40+ [18]. One reason for this categorization is that it gives time to take proactive measures [81]. Research on education later in life often concerns an older age group. When it comes to older adults in the workplace, many studies concentrate on age discrimination and decrease in physical ability. Contradictory, a focus on older adults' strengths tends to suggest that this group can make major contributions based on their experience, competence and skills [82]. Educational and vocational guidance is another important dimension that enables older adults to find their place in work life [83]. However, even when it comes to HR interventions, there is a crucial difference between what is considered important in order to keep older employees in the organization and what is actually done to keep them [84].

Most of the studies in our review concern countries from the Western world, but even so, the material does not offer possibilities for drawing conclusions on a general level in respect to our research questions. However, an example from the Swedish society might be the predominant understanding that the older workforce "should" step back in favor of the younger generation entering the labor market. 
This is in sharp contrast to the national policy advocating prolonged work life for older people. The idea that the older workforce is "consumed" and should be replaced by younger generations is an example of how people are classified and discriminated against because of their age [85]. It has been shown that ageism in work places in Sweden is far more influential than ethnic discrimination [86], and is one of the principal obstacles to prolonged work life [87]. Further, it has been shown that it is not easy to replace competent and experienced senior workers with younger and inexperienced workers. This is problematic especially considering the increasing dependency ratio. Therefore, stereotypes need to be scrutinized to be able to change from encouraging retirement to arguing for a continuing, flexible work life. The general answer from national economists [88] is that there is no support for the idea that older adults leaving the labor market would be beneficial.

In the material, a gap is hinted at between the need for employees working beyond their retirement age and the welfare sector's need to meet the demand for voluntary care of the growing number of older persons. Voluntary care was hitherto done mainly by women who left the labor market earlier and hence received lower pensions. Consequently, there is an obvious risk of a future gender gap in the labor market with consequences for women's private finances. The gender dimension was however not prominent in the articles reviewed.

To maintain reasonable living standards for increasing fractions of older people via sustainable public pension systems is a worldwide challenge. While mere fine tuning of benefits and revenues in the pension system may yield financial balance in the short run, a prolonged working life will have more permanent positive effects on the financing and sustainability of the pension system. This means a shift from the pension system as the main question to how a sustainable pro-longed working life could be realized. In order to prolong working life, people have to want, be able and allowed to postpone retirement. With our review, we put forward a theoretical framework that could be extended into a contextual analysis as a basis for policy work. In our framework three system levels are combined; with supporting or hindering factors related to motivation (wanting to work), health, wellbeing and skill (being able to work) and system structure (being allowed to work). The 58 reviewed research articles represent a variety of contexts and are based on different types of data but yield some universal insights. Financial gain is identified on all three levels as important for a prolonged work life. On the individual and organizational levels, good health, relevant education and skills in combination with flexible working conditions and benevolent attitudes to older workers, could be a way to understand why and how people can continue to work. To add to this complexity, older people should not be seen as a homogeneous group, but as having individual characteristics.

\section{Conclusions}

Some general policy implications for facilitating a prolonged working life may be identified from this study. Firstly, in order to make older individuals want to postpone retirement, the tax and pension system (including e.g. housing benefits for retirees) must be coordinated ensuring that continuing to work yields a sufficiently large individual monetary net gain. Secondly, in order to make them able and well equipped to meet the requirements for laborers in the modern world, they have to be given educational opportunities throughout their career. Hence, there is a need for decision makers at the macro and meso level to come together in order to create a viable system for lifelong learning in the workplace. Thirdly, similar arguments may be raised when it comes to the health status of older workers. A prolonged working life implies that work related injuries and attritional wear must be brought down, especially in industries and occupations where the incidence is high. Otherwise, an average increase in retirement age may well result from its distribution becoming more dispersed, i.e. that highly educated people will work longer while wore down blue collars will not - creating even larger inequalities among the elderly. Fourthly, and finally, any kinds of implicit or explicit ageism on the labor market and in the workplace, must be battled. This could be achieved via a combination of legislation and public campaigns on the importance for a sustainable society of utilizing competencies within the work place for longer periods of time. That said, the precise measures should naturally be adapted to the context at hand. If policies for a prolonged work life are to be of relevance they need to be based on empirical investigations and take older people's experiences as their point of departure. This review is one way to summarize the extensive work performed by researchers in many countries. We hope that this will be of good use in policy making as well as for future studies. 


\section{Strengths and limitations of the literature search}

To strengthen the rigor of our study, the search for articles in five different databases were conducted by the librarian in collaboration with the researchers. This strategy provided an opportunity for the main authors to reach a consensus on the selection of articles. The contribution from two researchers belonging to the areas of older people's learning and national economy, added another strength of our study.

There is, however, a limitation in the literature search, as it was undertaken at three different times. The publication date and the time of update in a database are not necessarily the same. An update can include articles with an older publication date than the time of the update. Some of the five databases have a function for update search, while others do not have this. An update search finds additional, older articles, whereas a search for publication date can only find newly published additions. One consequence of this was that articles already found in one database in the first search, could appear in another database and were consequently excluded as duplicates in the selection procedure, when the update searches were performed.

\section{Acknowledgments}

The authors thank Åke Wahlin (no longer with us), Professor in Gerontology, Jönköping University, School of Health and Welfare, Institute of Gerontology for his valuable support in this project.

\section{Conflict of interest}

None to report.

\section{References}

[1] Bengtsson T, Scott K. Population aging and the future of the welfare state: The example of Sweden. Popul Dev Rev. 2011;37(Suppl 1):158-70.

[2] Palme J. Why the Scandinavian experience is relevant for the reform of the ESM. In: Policy Network, ed. The Hampton Court Agenda: A Social Model for Europe. London: Policy Network, 2006:37-47.

[3] Jegermalm M, Grassman EJ. Helpful citizens and caring families: Patterns of informal help and caregiving in Sweden in a 17-year perspective. Int $\mathrm{J}$ Soc Welfare. 2012;21(4):422-32.
[4] Lee YG, Brown SM. Effects of human capital on the likelihood of working in later life. Hallym Int $\mathbf{J}$ Aging. 2009;11(2):155-72.

[5] Amabile TM. Motivational synergy: Toward new conceptualizations of intrinsic and extrinsic motivation in the workplace. Hum Resource Manag Rev. 1993;3(3):185-201.

[6] Rita C, Mieke H. HR professionals' views on work motivation and retention of older workers: A focus group study. Career Dev Int. 2008;13(2):95-111.

[7] Kanfer R, Ackerman PL. Aging, adult development, and work motivation. Acad Manage Rev. 2004;29(3): 440-58.

[8] Kooij D, de Lange A, Jansen P, Dikkers J. Older workers' motivation to continue to work: Five meanings of age. J Manag Psychol. 2008;23(4):364-94.

[9] Kooij D, Jansen P, Dikkers J, de Lange A. Managing aging workers: A mixed methods study on bundles of HR practices for aging workers. Int J Hum Resource Manag. 2014;25(15):2192-212.

[10] Kanfer R, Beier ME, Ackerman PL. Goals and motivation related to work in later adulthood: An organizing framework. Eur J Work Organ Psychol. 2013;22(3):253-64.

[11] de Lange AH, Van Yperen NW, Van der Heijden BIJM, Bal PM. Dominant achievement goals of older workers and their relationship with motivation-related outcomes. J Vocat Behav. 2010;77(1):118-25.

[12] Shultz K. Bridge employment: Work after retirement. In: Beehr TA, Adams GA, eds. Retirement: Reasons, Processes, and Results: Springer Publishing Company; 2003: 214-41.

[13] Beehr TA, Bennett MM. Working after retirement: Features of bridge employment and research directions. Work, Aging and Retirement. 2015;1(1):112-28.

[14] Alcover C-M, Topa G, Parry E, Fraccaroli F, Depolo M, eds. Bridge Employment: A Research Handbook. London: Routledge; 2014.

[15] Swedish Pensions Agency. Appropriation assignment. Labor market entry age and pension rights year. (In Swedish: Pensionsmyndigheten. Regleringsbrevsuppdrag. Inträdesålder på arbetsmarknaden och antal år med pensionsrätt.) [Website]. Stockholm: The Agency; 2013; Cited Nov 26, 2014. Available from: http://docplayer.se/357438Regleringsbrevsuppdrag-intradesalder-pa-arbetsmarknade n-och-antal-ar-med-pensionsratt.html

[16] Parry E, Bown Wilson D. Career transitions at retirement age in the United Kingdom: Bridge employment or continued career progression? In: Alcover C-M, Topa G, Parry E, Fraccaroli F, Depolo M, eds. Bridge Employment: A Research Handbook. London: Routledge; 2014:138-53.

[17] Reynolds F, Farrow A, Blank A. 'Otherwise it would be nothing but cruises': Exploring the subjective benefits of working beyond 65. International Journal of Ageing and Later Life. 2012;7(1):79-106.

[18] Fuller A, Unwin L. Older workers' learning in changing workplace contexts: Barriers and opportunities. In: Tikkanen T, Nyhan B, eds. Promoting Lifelong Learning for Older Workers: An International Overview. Luxembourg: Office for Official Publications of the European Communities; 2006:257-70

[19] Arksey H, O'Malley L. Scoping studies: Towards a methodological framework. Int J Soc Res Meth. 2005;8(1): 19-32.

[20] Coughlan M, Ryan F, Cronin P. Doing a Literature Review in Nursing, Health and Social Care. London: Sage; 2013. 
[21] Cahill KE, Giandrea MD, Quinn JF. Retirement patterns and the macroeconomy, 1992-2010: The prevalence and determinants of bridge jobs, phased retirement, and reentry among three recent cohorts of older Americans. Gerontologist. 2015;55(3):384-403.

[22] Pengcharoen C, Shultz KS. The influences on bridge employment decisions. Int J Manpow. 2010;31(3):32236.

[23] Clark RL, Ogawa N, Lee S-H, Matsukura R. Older workers and national productivity in Japan. Population and Development Review. 2008;34:257-74.

[24] Hammerman-Rozenberg R, Maaravi Y, Cohen A, Stessman J. Working late: The impact of work after 70 on longevity, health and function. Aging Clin Exp Res. 2005;17(6): 508-13.

[25] Patrickson M. Working and employability after 75 in Australia. Asia Pac J Hum Resour. 2016;54(2):188-206.

[26] Kerr G, Armstrong-Stassen M. The bridge to retirement: Older workers' engagement in post-career entrepreneurship and wage-and-salary employment. J Enterpren. 2011;20(1):55-76.

[27] Brown P, Vickerstaff S. Health subjectivities and labor market participation: Pessimism and older workers' attitudes and narratives around retirement in the United Kingdom. Res Aging. 2011;33(5):529-50.

[28] Wang M, Zhan Y, Liu S, Shultz KS. Antecedents of bridge employment: A longitudinal investigation. J Appl Psychol. 2008;93(4):818-30.

[29] Nobahar M, Ahmadi F, Alhani F, Khoshknab MF. Work or retirement: Exploration of the experiences of Iranian retired nurses. Work. 2015;51(4):807-16.

[30] Ozawa MN, Lum TY. Men who work at age 70 or older. J Gerontol Soc Work. 2005;45(4):41-63.

[31] Nilsson K, Hydbom AR, Rylander L. Factors influencing the decision to extend working life or retire. Scand J Work Environ Health. 2011;37(6):473-80.

[32] McEvoy GM, Henderson S. The retention of workers nearing retirement: A job embeddedness approach. J Workplace Behav Health. 2012;27(4):250-71.

[33] Carmichael F, Hulme C, Porcellato L. Older age and illhealth: Links to work and worklessness. Int J Workplace Health Manag. 2013;6(1):54-65.

[34] Fasbender U, Deller J, Wang M, Wiernik BM. Deciding whether to work after retirement: The role of the psychological experience of aging. J Vocat Behav. 2014; 84(3):215-24.

[35] Lu L. Attitudes towards aging and older people's intentions to continue working: A Taiwanese study. Career Dev Int. 2012;17(1):83-98.

[36] Müller A, De Lange A, Weigl M, Oxfart C, Van der Heijden B. Compensating losses in bridge employment? Examining relations between compensation strategies, health problems, and intention to remain at work. $\mathrm{J}$ Vocat Behav. 2013;83(1):68-77.

[37] Dendinger VM, Adams GA, Jacobson JD. Reasons for working and their relationship to retirement attitudes, job satisfaction and occupational self-efficacy of bridge employees. Int J Aging Hum Dev. 2005;61(1):21-35.

[38] Loi JLP, Shultz KS. Why older adults seek employment: Differing motivations among subgroups. J Appl Gerontol. 2007;26(3):274-89.

[39] Templer A, Armstrong-Stassen M, Cattaneo J. Antecedents of older workers' motives for continuing to work. Career Dev Int. 2010;15(5):479-500.
[40] Ulrich LB, Brott PE. Older workers and bridge employment: Redefining retirement. J Employ Counsel. 2005;42(4):159-70.

[41] Marañon NS. Redefining the sunset years: The lived experiences of retired university educators in bridge employment. Journal of Institutional Research South East Asia. 2012;10(1):38-52.

[42] Ling DC, Chi I. Determinants of work among older adults in urban China. Australas J Ageing. 2008; 27(3):126-33.

[43] Simpson M, Richardson M, Zorn TE. A job, a dream or a trap? Multiple meanings for encore careers. Work Employ Soc. 2012;26(3):429-46.

[44] Chen J, Chuang CH. Phased retirement for older workers in Taiwan. J Fam Econ Issues. 2012;33(3):328-37.

[45] Hébert BP, Luong M. Bridge employment. Perspect Lab Income. 2008;9(11):5-12.

[46] von Bonsdorff ME, Shultz KS, Leskinen E, Tansky J. The choice between retirement and bridge employment: A continuity theory and life course perspective. Int J Aging Hum Dev. 2009;69(2):79-100.

[47] Dorfman LT. Ten years later: A follow-up study of professors still working after age 70. Educ Gerontol. 2009;35(11):1032-45.

[48] van Solinge H. Who opts for self-employment after retirement? A longitudinal study in the Netherlands. Eur J Ageing. 2014;11(3):261-72.

[49] Hennekam S. Employability of older workers in the Netherlands: Antecedents and consequences. Int $\mathrm{J}$ Manpow. 2015;36(6):931-46.

[50] Venneberg DL, Wilkinson VD. Retirees who returned to work: Human and social capital implications for organizations. J Workplace Behav Health. 2008;23(1-2): $1-15$.

[51] Dingemans E, Henkens K. Involuntary retirement, bridge employment, and satisfaction with life: A longitudinal investigation. J Organ Behav. 2014;35(4):575-91.

[52] Oakman J, Howie L. How can organisations influence their older employees' decision of when to retire? Work. 2013;45(3):389-97

[53] Jaimie CT, Allison CH, Sheila LF, Sheila LF, Migliore A. Retaining the older workforce: Social policy considerations for the universally designed workplace. J Aging Soc Policy. 2011;23(2):119-40.

[54] Angeloni S, Borgonovi E. An ageing world and the challenges for a model of sustainable social change. J Manag Dev. 2016;35(4):464-85.

[55] Frerichs F, Lindley R, Aleksandrowicz P, Baldauf B, Galloway S. Active ageing in organisations: A case study approach. Int J Manpow. 2012;33(6):666-84.

[56] Sanders MJ, McCready J. Meeting the challenge of supervising older workers in the retail homebuilding industry. Journal of Business \& Retail Management Research. 2011;5(2):17-30.

[57] Proper KI, Deeg DJ, van der Beek AJ. Challenges at work and financial rewards to stimulate longer workforce participation. Hum Resour Health. 2009;7(1):1-13.

[58] Armstrong-Stassen M, Ursel ND. Perceived organizational support, career satisfaction, and the retention of older workers. J Occup Organ Psychol. 2009;82(1):201-20.

[59] Fraser L, McKenna K, Turpin M, Allen S, Liddle J. Older workers: An exploration of the benefits, barriers and adaptations for older people in the workforce. Work. 2009;33(3):261-72. 
[60] Johnson RW, Mermin GBT, Resseger M. Job demands and work ability at older ages. J Aging Soc Policy. 2011;23(2):101-18.

[61] McCann RM, Keaton SA. A cross cultural investigation of age stereotypes and communication perceptions of older and younger workers in the USA and Thailand. Educ Gerontol. 2013;39(5):326-41.

[62] Gringart E, Helmes E, Speelman CP. Exploring attitudes toward older workers among Australian employers: An empirical study. J Aging Soc Policy. 2005;17(3): 85-103.

[63] Lain D. Working past 65 in the UK and the USA: Segregation into 'Lopaq' occupations? Work Employ Soc. 2012;26(1):78-94.

[64] Flynn M. The United Kingdom government's 'business case' approach to the regulation of retirement. Ageing Soc. 2010;30(3):421-43.

[65] Cebulla A, Butt S, Lyon N. Working beyond the state pension age in the United Kingdom: The role of working time flexibility and the effects on the home. Ageing Soc. 2007;27(6):849-67.

[66] Boyce RW. An ergonomic approach to the aging workforce utilizing this valuable resource to best advantage by integrating ergonomics, health promotion and employee assistance programs. J Workplace Behav Health. 2008; 23(1-2):179-99.

[67] Cochran J, Crowne KA, Carpenter CE. Impact of older-worker-friendly organizational policies on retirement attitudes and planning. Organisation Management Journal. 2012;9(3):170-8.

[68] Conen WS, Henkens K, Schippers J. Employers' attitudes and actions towards the extension of working lives in Europe. Int J Manpow. 2012;33(6):648-65.

[69] Bal M, Visser MS. When are teachers motivated to work beyond retirement age? The importance of support, change of work role and money. Educ Manag Admin Leader. 2011;39(5):590-602.

[70] Schmidt L, Sevak P. Taxes, wages, and the labor supply of older Americans. Res Aging. 2009;31(2):207-32.

[71] De Preter H, Van Looy D, Mortelmans D. Individual and institutional push and pull factors as predictors of retirement timing in Europe: A multilevel analysis. J Aging Stud. 2013;27(4):299-307.

[72] Shannon M, Grierson D. Mandatory retirement and older worker employment. Canadian Journal of Economics. 2004;37(3):528-51.

[73] Mermin GBT, Johnson RW, Murphy DP. Why do boomers plan to work longer? J Gerontol B Psychol Sci Soc Sci. 2007;62(5):S286-94.

[74] Gustman AL, Steinmeier T. How changes in social security affect recent retirement trends. Res Aging. 2009; 31(2):261-90.
[75] McNamara TK, Williamson JB. Race, gender, and the retirement decisions of people ages 60 to 80: Prospects for age integration in employment. Int J Aging Hum Dev. 2004;59(3):255-86.

[76] Moen P, Flood S. Limited engagements? Women's and men's work/volunteer time in the encore life course stage. Soc Probl. 2013;60(2):206-33.

[77] Anxo D, Ericson T, Jolivet A. Working longer in European countries: Underestimated and unexpected effects. Int J Manpow. 2012;33(6):612-28.

[78] Quine S, Carter S. Australian baby boomers' expectations and plans for their old age. Australas J Ageing. 2006;25(1):3-8

[79] OECD. Average effective age of retirement versus the normal age in 2014 in OECD countries. [Website]. 2014; Cited Nov 26, 2014. Available from: http://www.oecd.org/els/pub lic-pensions/ageingandemploymentpolicies-statisticsonave rageeffectiveageofretirement.htm

[80] Stamov-Roßnagel C, Hertel G. Older workers' motivation: Against the myth of general decline. Manag Decis. 2010;48(6):894-906.

[81] Ilmarinen JE. Aging workers. Occup Environ Med. 2001;58(8):546-52.

[82] Östlund B. Work longer - what do we know about older people in work life? (In Swedish: Jobba längre-vad vet vi om äldre i arbetslivet). Stockholm: Arbetsmiljöverket; 2012. Rapport 2012:10.

[83] Cummins PA. Effective strategies for educating older workers at community colleges. Educ Gerontol. 2014; 40(5):338-52.

[84] Aaltio I, Salminen HM, Koponen S. Ageing employees and human resource management - evidence of gendersensitivity? Equality, Diversity \& Inclusion. 2014;33(2): 160-76.

[85] Barusch AS, Luptak M, Hurtado M. Supporting the labor force participation of older adults: An international survey of policy options. J Gerontol Soc Work. 2009;52(6):584-99.

[86] Isaksson K, Johansson G, Palm S. Bridge employment, a Swedish perspective. In: Alcover C-M, Topa G, Parry E, Fraccaroli F, Depolo M, eds. Bridge Employment: A Research Handbook. London: Routledge; 2014:51-69.

[87] Pensionsåldersutredningen. Measures for a longer work life: Final report. (In Swedish: Åtgärder för ett längre arbetsliv: Slutbetänkande). Stockholm: Fritze; 2013. Statens offentliga utredningar SOU, 2013:25.

[88] Pensionsåldersutredningen. Longer life, longer work life. Prerequisites and obstacles to older people working longer: Interim report. (In Swedish: Längre liv, längre arbetsliv: förutsättningar och hinder för äldre att arbeta längre: delbetänkande). Stockholm: Fritze; 2012. Statens offentliga utredningar SOU, 2012:28. 